\title{
How successful are motivation theories in practice?
}

\author{
F.W. Marx \\ Department of Business Administration, University of Pretoria, Pretoria
}

\begin{abstract}
In this study, 503 South African companies are used to ascertain the utilization of various important theories of motivation. Furthermore, utilizing the questionnaire method, the perceived success of the various theories and practices with the main South African population groups was assessed. The findings are of great importance: motivation theories are not applied extensively; but perhaps of greater importance is the linding that companies report less than $50 \%$ success rate in the application of these theories.
\end{abstract}

S. Afr. J. Bus. Mgmt. 1983, 14: $60-65$

In hierdie studie word 503 Suid-Afrikaanse maatskappye se gebruik van en sukses in die toepassing van motiveringsteoriee geëvalueer.

Die bevindinge is van groot belang: Suid-Afrikaanse maatskappye maak nie baie gebruik van motiveringsteorie nie maar verder, rapporteer ' $n$ suksesratio van minder as $50 \%$ in die toepassing van hierdie teorie.

S.-Afr. Tydskr. Bedryfsl. 1983, 14: 60-65

\section{Introduction}

During the last four to five decades the motivation of employees has reccived much attention in many countries all over the world. Various practitioners and researchers have come forward with several theories and ideas on the subject of employee motivation. In South Africa also employers have been inundated with lectures, seminars, short courses, publications and the like on personnel motivation in order to improve employee morale and worker performance. Indeed, quite a few of the world's leading motivation theorists and practitioners have visited the country personally to participate in such courses and seminars and have made themselves available for in-company teaching and training courses.

In order to ascertain to what extent South African companies are using the motivation theories and ideas of internationally reputed persons and what measure of success is attained in using these theories/ideas, a comprehensive survey was carried out during 1980 and 1981.

\section{Particulars of the survey}

A questionnaire was sent to a total number of 503 South African companies, mainly those listed on the Johannesburg Stock Exchange. These companies were selected firstly on account of the fact that they were regarded as large enough to have personnel departments which could take the initiative in using motivation theories and be able to incur the additional costs involved in the application of motivation theories. Secondly, since one would expect them to be interested in applying all available methods to improve company performance because of the rating of their shares on the Stock Exchange. The questionnaire, inter alia, asked for information on the following aspects:

(a) Whether any of the motivation theories or ideas of 13 persons mentioned in the questionnaire or of any other persons are being or have been used in the company in respect of the following 11 categories of employees:

(i) Top management.

(ii) Middle management.

(iii) Lower management.

(iv) White white collar workers.

(v) White blue collar workers.

(vi) Coloured white collar workers.

(vii) Coloured blue collar workers.

(viii) Asian white collar workers. 
Table 1 Details of the participating companies

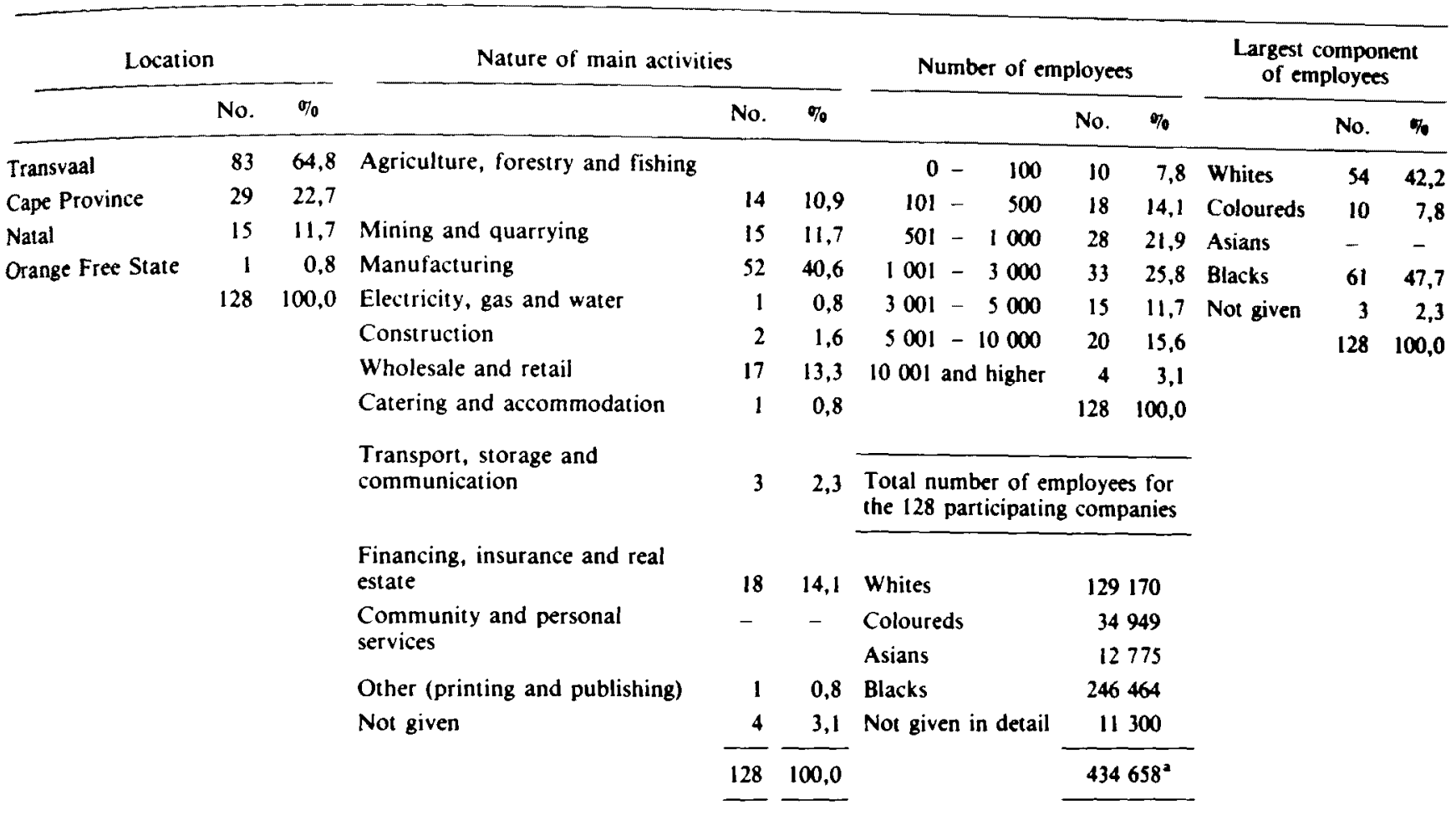

These figures are not 100 per cent correct since a few participants did not provide full details.

(ix) Asian blue collar workers.

(x) Black white collar workers.

(xi) Black blue collar workers. ${ }^{\text {a }}$

(b) The success obtained in the application of the various persons' theories or ideas, rated according to a given scale, for each of the said 11 categories of employees.

Despite the careful selection of potential participants, and notwithstanding numerous reminder letters, telephone calls to managing directors and personnel, training and other managers, duplicate questionnaires addressed to specific personnel as well as personal visits to several firms over a long period of time, a total number of only 128 completed questionnaires (a response of 25,4 per cent) could be obtained.

The questionnaires were mostly completed by a Personnel or Manpower Manager or another person in the personnel department, namely in 68 cases $(53,1$ per cent). Other persons completing the questionnaires were Training Managers/Officers in 13 instances (10,2 per cent), Secretaries in 12 cases $(9,4$ per cent), Chief Executives in 11 instances $(8,6$ per cent), Directors in seven cases $(5,5$ per cent), Accountants in five instances ( 3,9 per cent), Administrative Managers in four cases ( 3,1 per cent), and by various other persons, such as a Financial Manager, Controller, Planning Manager, Marketing Manager, and Research and Development Manager in one instance each. This information shows that in most of the participating companies personnel matters are administered by either a personnel department or a senior official. It also indicates

\footnotetext{
"It was considered essential to distinguish between the various groups in order to ascertain whether the success of a particular person's theory or ideas could be correlated with a particular managment level and/or cultural group.
}

that the questionnaires were completed by responsible and senior staff members and that the information supplied can be regarded as correct and reliable.

Details concerning the participating companies in regard to their location, the nature of their activities, the number of employees and the race group which constitutes the largest component of the work force, are given in Table 1.

Table 1 reveals that the participating companies are geographically well spread, that they represent a variety of activities in various sectors of the economy, that the majority ( 56,2 per cent) have more than 1000 employees each, and that together they employ almost half a million persons of all race groups, i.e. approximately six per cent of the estimated total work force of the private sector at the time the survey was carried out.

\section{The results of the survey}

The most important findings of the survey are as follows:

\section{Extent of use of motivation theories/ideas}

The extent to which the various motivation theories were used in respect of the 11 personnel groups is shown in Table 2.

It is clear that the various motivation theories/ideas have not been used very extensively by the participating companies. The highest percentage application of any theory in respect of any personnel group was $44,5 \%$ only, namely Maslow's theory in the case of middle management. In only two other cases the application rate reached $40 \%$, namely the theory of Herzberg in respect of top and middle management. In quite a number of instances the application rate of the most popular theories never reached $30 \%$ and in a few instances it was below $20 \%$.

It is also clear that, in general, the motivation theories/ 
Table 2 Comparison between the use of the various motivation theories in respect of the various groups of personnel (Percentage of total participants using the theories)

\begin{tabular}{|c|c|c|c|c|c|c|c|c|c|c|c|c|}
\hline \multirow{3}{*}{ Motivation theory } & \multicolumn{3}{|c|}{ Mamagement personnd } & \multicolumn{2}{|c|}{ White workers } & \multicolumn{2}{|c|}{ Coloured workers } & \multicolumn{2}{|c|}{ Asian workers } & \multicolumn{2}{|c|}{ Black workers } & \multirow[b]{2}{*}{ Average usage } \\
\hline & Top & Middle & Lower & $\begin{array}{l}\text { White } \\
\text { collar }\end{array}$ & $\begin{array}{l}\text { Blue } \\
\text { collar }\end{array}$ & $\begin{array}{l}\text { White } \\
\text { collar }\end{array}$ & $\begin{array}{l}\text { Blue } \\
\text { collar }\end{array}$ & $\begin{array}{l}\text { White } \\
\text { collar }\end{array}$ & $\begin{array}{l}\text { Blue } \\
\text { collar }\end{array}$ & $\begin{array}{l}\text { White } \\
\text { collar }\end{array}$ & $\begin{array}{l}\text { Blue } \\
\text { collar }\end{array}$ & \\
\hline & $\boldsymbol{\$}$ & $\%$ & $\%$ & $\%$ & $\%$ & $\%$ & $\%$ & $\%$ & $\%$ & $\%$ & $\%$ & $\%$ \\
\hline Mayo & 11.7 & 10,9 & 11,7 & 8,6 & 7,0 & 6,3 & 5,5 & 5,5 & 5,5 & 7,8 & 6,3 & 7,9 \\
\hline Roechlisberger & 3,1 & 3,1 & 2,3 & 3,1 & 3,1 & 2,3 & 3,1 & 2,3 & 3,1 & 3,9 & 3,9 & 3,0 \\
\hline McGregor & 32,9 & 34.4 & 34,4 & 30.5 & 21,9 & $2 l, 2$ & 20,3 & 19,5 & 18,0 & 22,7 & 19,5 & 25,0 \\
\hline Maslow & 39,8 & 4,5 & 39,8 & 39,1 & 31.2 & 29,7 & 28,1 & 25,1 & 22,7 & 33,6 & 29,7 & 33,0 \\
\hline Herzberg & 40,6 & 41,5 & 39,8 & 37,5 & 28,9 & 25,8 & 25,1 & 22,7 & 21,2 & 32,9 & 28,1 & 31,3 \\
\hline MaClelland & 17,2 & 17,2 & 14,9 & 14,1 & 10,2 & 10,9 & 8,6 & 9,4 & 6,3 & 13,3 & 7,8 & 11,8 \\
\hline Likert & 14,1 & 17,2 & 11,7 & 12,5 & 8,6 & 7,0 & 7,8 & 6,3 & 4,7 & 7,0 & 7,0 & 9,4 \\
\hline Vroom & 7,0 & 5,5 & 4,7 & 4,7 & 4,7 & 3,9 & 7,8 & 1,6 & 2,3 & 1,6 & 1,6 & 4,1 \\
\hline Lawler & 8,6 & 9,4 & 6,3 & 5,5 & 3,9 & 3,1 & 3,1 & 2,3 & 2,3 & 2,3 & 2,3 & 4,5 \\
\hline Schein & 8.6 & 7,8 & 6,3 & 3,9 & 3,1 & 1,6 & 1,6 & 0,8 & 0,8 & 1,6 & 1,6 & 3,4 \\
\hline Skinner & 8,6 & 8,6 & 8,6 & 10,2 & 10,9 & 9,4 & 9,4 & 7,8 & 7,0 & 7,8 & 7,8 & 8,7 \\
\hline Blake \& Mouton & 32,9 & 32,9 & 22,7 & 19,5 & 8,6 & 10,2 & 6,3 & 8,6 & 7,8 & 9,4 & 7,0 & 15,1 \\
\hline Gellerman & 15,6 & 15,6 & 10,2 & 12,5 & 7,8 & 8,6 & 6,3 & 5,5 & 5,5 & 5,5 & 5,5 & 9,0 \\
\hline Ohers" & 5,5 & 7,0 & 6,3 & 3,9 & 2,3 & 3,1 & 2,3 & 1,6 & 2,3 & 1,6 & 2,3 & 3,5 \\
\hline
\end{tabular}

These indude W.J. Reddin, Mintzberg. J. Window, E. Berne, Hersey \& Blanchard, L.A. Allen, B. Byham and Kepner \& Tregoe

ideas were used more often in respect of management personnel and White white collar workers, than in respect of the other groups. In the case of the former the application percentages of the three most popular theories varied between $30,5 \%$ and $44,5 \%$. In the case of the latter the application percentages varied between $18 \%$ and $33,6 \%$.

The most popular motivation theories

Table 2 also shows that in respect of all personnel groups the theories of Maslow, Herzberg and McGregor were used most frequently, with the theory of Blake and Mouton being quite popular in the case of top and middle management.

In the case of top management Herzberg's theory had the highest application rate, in the case of lower manage- ment the theories of Herzberg and Maslow were used most often, but in the case of all the other groups, Maslow's theory was used most frequently.

On average Maslow's theory was most popular with an application rate of $33,0 \%$, followed by Herzberg $(31,3 \%)$ and McGregor $(25,0 \%)$.

The theories/ideas used least were those of Roethlisberger (average application $3,0 \%)$, Schein $(3,4 \%)$, Vroom $(4,1 \%)$ and Lawler $(4,5 \%)$.

Success attained using motivation theories/ideas Details of the successfulness of the various motivation theories/ideas in respect of the various personnel groups are given in Tables 3,4 and 5 .

Table 3 Comparison between the successfulness of the various motivation theories/ideas in respect of the various personnel groups (Percentage of users experiencing no success at all)

\begin{tabular}{|c|c|c|c|c|c|c|c|c|c|c|c|c|}
\hline \multirow{3}{*}{$\begin{array}{l}\text { Motivation } \\
\text { theory/idea }\end{array}$} & \multicolumn{3}{|c|}{ Management personned } & \multicolumn{2}{|c|}{ White workers } & \multicolumn{2}{|c|}{ Coloured workers } & \multicolumn{2}{|c|}{ Asian workers } & \multicolumn{2}{|c|}{ Black workers } & \multirow[b]{2}{*}{ Average } \\
\hline & Top & Middle & Lower & $\begin{array}{l}\text { White } \\
\text { collar }\end{array}$ & $\begin{array}{l}\text { Blue } \\
\text { collar }\end{array}$ & $\begin{array}{l}\text { White } \\
\text { collar }\end{array}$ & $\begin{array}{l}\text { Blue } \\
\text { collar }\end{array}$ & $\begin{array}{l}\text { White } \\
\text { collar }\end{array}$ & $\begin{array}{l}\text { Blue } \\
\text { collar }\end{array}$ & $\begin{array}{l}\text { White } \\
\text { collar }\end{array}$ & $\begin{array}{l}\text { Blue } \\
\text { collar }\end{array}$ & \\
\hline & $\%$ & $\%$ & $\%$ & $\%$ & $\%$ & $\%$ & $\%$ & $\%$ & $\%$ & $\%$ & $\%$ & $\%$ \\
\hline Mayo & 13,3 & - & - & - & - & - & - & - & - & 10,0 & - & 2,2 \\
\hline Roethlisberger & - & - & - & - & - & - & - & - & - & - & - & - \\
\hline McGregor & 2,4 & 2,2 & 2,3 & 2,6 & - & - & - & 8,0 & 8,6 & 6,9 & 4,0 & 3,4 \\
\hline Maslow & - & - & - & - & - & - & - & 3,1 & 3,5 & 2,3 & 2,6 & 1,0 \\
\hline Herzberg & - & 1,9 & - & - & 2,7 & - & - & - & - & 4,8 & 8,3 & 1,6 \\
\hline McClelland & - & - & - & - & - & 7,1 & - & - & - & - & 50,0 & 5,2 \\
\hline Liken & - & - & 6,6 & - & 9,1 & 11,1 & 10,0 & - & - & 22,3 & 11,1 & 6,4 \\
\hline Vroom & - & - & - & 16,7 & 16,7 & 20,0 & 10,0 & - & - & - & - & 5,8 \\
\hline Lawler & - & - & - & - & - & - & - & - & - & - & - & - \\
\hline Schein & - & - & - & - & - & - & - & 100,0 & - & - & - & 9,1 \\
\hline Skinner & - & - & - & - & - & - & - & - & - & - & 10,0 & 0,9 \\
\hline Blake \& Mouton & 2,4 & 2,4 & 3,4 & - & - & - & - & 18,2 & 20,0 & 16,7 & 22,3 & 7,8 \\
\hline Gedkerman & 10,0 & 5,0 & - & 12,5 & 10,0 & - & - & - & - & - & 14,3 & 4,7 \\
\hline Otbers & - & - & - & - & - & - & - & - & - & - & - & - \\
\hline Total & 1,9 & 1,2 & 1,1 & 1,5 & 2,1 & 1,6 & 1,2 & 3,9 & 3,6 & 5,2 & 9,0 & 2.9 \\
\hline
\end{tabular}


Table 4 Comparison between the successfulness of the various motivation theories/ideas in respect of various personnel groups (Percentage of users experiencing a success rate of $1 \%$ to $49 \%$ )

\begin{tabular}{|c|c|c|c|c|c|c|c|c|c|c|c|c|}
\hline \multirow{3}{*}{$\begin{array}{l}\text { Motivation } \\
\text { theory/idea }\end{array}$} & \multicolumn{3}{|c|}{ Managernent personnel } & \multicolumn{2}{|c|}{ White workers } & \multicolumn{2}{|c|}{ Coloured workets } & \multicolumn{2}{|c|}{ Asian workers } & \multicolumn{2}{|c|}{ Black workers } & \multirow[b]{2}{*}{ Avetage } \\
\hline & Top & Middle & Lower & $\begin{array}{l}\text { White } \\
\text { collar }\end{array}$ & $\begin{array}{c}\text { Blue } \\
\text { collar }\end{array}$ & $\begin{array}{l}\text { White } \\
\text { collar }\end{array}$ & $\begin{array}{l}\text { Blue } \\
\text { collar }\end{array}$ & $\begin{array}{l}\text { White } \\
\text { collar }\end{array}$ & $\begin{array}{l}\text { Blue } \\
\text { collar }\end{array}$ & $\begin{array}{l}\text { White } \\
\text { collar }\end{array}$ & $\begin{array}{c}\text { Blue } \\
\text { collar }\end{array}$ & \\
\hline & $\%$ & $\%$ & $\%$ & $\%$ & $\%$ & $\%$ & $\%$ & $\%$ & $\%$ & $\%$ & $\%$ & $\%$ \\
\hline Mayo & 46,6 & 57,1 & 53,3 & 45,5 & 55,6 & 37,5 & 42,9 & 57,1 & 57,1 & 60,0 & 50,0 & 51,2 \\
\hline Roethlisberger & 100,0 & 100,0 & 100,0 & 100,0 & 75.0 & 66,7 & 50,0 & 100,0 & 100,0 & 80,0 & 60,0 & 84,7 \\
\hline MoGregor & 45,2 & 56,8 & 70,4 & 64,1 & 57,2 & 66,7 & 80,9 & 64,0 & 65.4 & 72,4 & 60,0 & 63,9 \\
\hline Maslow & 53,0 & 54,2 & 53,0 & 62,0 & 65,0 & 57,9 & 64,0 & 59,4 & 62,0 & 60,4 & 63,2 & 59,5 \\
\hline Herzberg & 57.5 & 57,0 & 58,8 & 60,5 & 64,8 & 51,5 & 68,7 & 58,6 & 62,9 & 64,2 & 63,9 & 60,8 \\
\hline MoClelland & 40,9 & 50,0 & 57,9 & 66,6 & 84,6 & 71,5 & 100,0 & 41,7 & 75,0 & 70,6 & 50,0 & 64,4 \\
\hline Liker & 66,7 & 68,2 & 66,7 & 81,3 & 81,8 & 88,9 & 90,0 & 87,5 & 66,6 & 77,7 & 66,6 & 76,5 \\
\hline Vroom & 77,8 & 71,4 & 66,6 & 50,0 & 83,3 & 60,0 & 90,0 & 100,0 & 100,0 & 100,0 & 50,0 & 77,2 \\
\hline Lawler & 72,8 & 66,7 & 62,5 & 71,4 & 80,0 & 50,0 & 75,0 & 66,6 & 66,7 & 66,7 & 66,7 & 67,7 \\
\hline Schein & 63,6 & 70,0 & 75,0 & 20,0 & 25,0 & 50,0 & - & - & - & 100,0 & 100,0 & 45,8 \\
\hline Skinner & 81,6 & 72,7 & 45,4 & 61,5 & 71,4 & 50,0 & 58,3 & 70,0 & 44,4 & 60,0 & 40,0 & 59,6 \\
\hline Blake \& Mouton & 57,2 & 64,4 & 62,2 & 64,0 & 81,8 & 77,0 & 75,0 & 54,6 & 60,0 & 66,7 & 66,6 & 66,3 \\
\hline Gellerman & 50,0 & 60,0 & 69,2 & 68,8 & 60,0 & 63,6 & 75,0 & 57,2 & 57,2 & 57,2 & 42,9 & 60,1 \\
\hline Others & - & 11,1 & 25,0 & 40,0 & 33,3 & 25,0 & 33,3 & - & - & - & - & 15,2 \\
\hline Total & 54,9 & 58,7 & 60,1 & 62,7 & 66,6 & 60,2 & 71,1 & 60,6 & 62,1 & 65,8 & 58,7 & 62,0 \\
\hline
\end{tabular}

Table 5 Comparison between the successfulness of the various motivation theories in respect of various groups of employees (Percentage of users experiencing a success rate of 50 per cent to 100 per cent)

\begin{tabular}{|c|c|c|c|c|c|c|c|c|c|c|c|c|}
\hline \multirow{3}{*}{$\begin{array}{l}\text { Motivation } \\
\text { theory }\end{array}$} & \multicolumn{3}{|c|}{ Management personnel } & \multicolumn{2}{|c|}{ White workers } & \multicolumn{2}{|c|}{ Coloured workers } & \multicolumn{2}{|c|}{ Asian workers } & \multicolumn{2}{|c|}{ Black workers } & \multirow[b]{2}{*}{$\begin{array}{l}\text { Average } \\
\text { success }\end{array}$} \\
\hline & Top & Middle & Lower & $\begin{array}{l}\text { White } \\
\text { collar }\end{array}$ & $\begin{array}{l}\text { Blue } \\
\text { collar }\end{array}$ & $\begin{array}{l}\text { White } \\
\text { collar }\end{array}$ & $\begin{array}{l}\text { Blue } \\
\text { collar }\end{array}$ & $\begin{array}{l}\text { White } \\
\text { collar }\end{array}$ & $\begin{array}{l}\text { Blue } \\
\text { collar }\end{array}$ & $\begin{array}{l}\text { White } \\
\text { collar }\end{array}$ & $\begin{array}{l}\text { Blue } \\
\text { collar }\end{array}$ & \\
\hline & $\%$ & $\%$ & $\%$ & $\%$ & $\%$ & $\%$ & $\%$ & $\%$ & $\%$ & $\%$ & $\%$ & $\%$ \\
\hline Mayo & 40,1 & 42,9 & 46,7 & 54,5 & 44,4 & 62,5 & 57,1 & 42,9 & 42,9 & 30,0 & 50,0 & 46,7 \\
\hline Roethlisberger & - & - & - & - & 25,0 & 33,3 & 50,0 & - & - & 20,0 & 40,0 & 15,3 \\
\hline MoGregor & 52,4 & 41,0 & 27,3 & 33,3 & 42,8 & 33,3 & 19,1 & 28,0 & 26,0 & 20,7 & 36,0 & 32,7 \\
\hline Maslow & 47,0 & 45,8 & 47,0 & 38,0 & 35,0 & 42,1 & 36,0 & 37,5 & 34,5 & 37,3 & 34,2 & 39.5 \\
\hline Herzberg & 42,5 & 41,1 & 41,2 & 39,5 & 32,5 & 48,5 & 31,3 & 41,4 & 37,1 & 31,0 & 27,8 & 37,6 \\
\hline McClelland & 59.1 & 50,0 & 42,1 & 33,4 & 15,4 & 21,4 & - & 58,3 & 25,0 & 29,4 & - & 30,4 \\
\hline Likert & 33,3 & 31,8 & 26,7 & 18,7 & 9,1 & - & - & 12,5 & 33,4 & - & 22,3 & 17,1 \\
\hline Vroom & 22,2 & 28,6 & 33,4 & 33,3 & - & 20,0 & - & - & - & - & 50,0 & 17,0 \\
\hline Lawler & 27,2 & 33,3 & 37,5 & 28,6 & 20,0 & 50,0 & 25,0 & 33,4 & 33,3 & 33,3 & 33,3 & 32,3 \\
\hline Schein & 36,4 & 30,0 & 25,0 & 80,0 & 75,0 & 50,0 & 100,0 & - & 100,0 & - & - & 45,1 \\
\hline Skinner & 18,4 & 27,3 & 54,6 & 38,5 & 28,6 & 50,0 & 41,7 & 30,0 & 55,6 & 10,0 & 50,0 & 39,5 \\
\hline Blake \& Mouton & 40,4 & 33,2 & 34,4 & 36,0 & 18,2 & 23,0 & 25,0 & 27,2 & 20,0 & 16,6 & 11,2 & 25,9 \\
\hline Gellerman & 40,0 & 35,0 & 30,8 & 18,7 & 30,0 & 36,4 & 25,0 & 42,8 & 42,8 & 42,8 & 42,8 & 35,2 \\
\hline Others & 100,0 & 88,9 & 75,0 & 60,0 & 66,7 & 75,0 & 66,7 & 100,0 & 100,0 & 100,0 & 100,0 & 79,6 \\
\hline Total & 43,2 & 40,1 & 38,8 & 35,8 & 31,3 & 38,2 & 27,7 & 35,5 & 34,3 & 29,0 & 32,3 & 35,1 \\
\hline
\end{tabular}

Table 3 provides details regarding the unsuccessful use of the various motivation theories/ideas. It reveals that 11 out of the 13 theories/ideas listed in the questionnaire were used with no success at all in respect of one or more of the 11 personnel groups. The exceptions were the theories/ideas of Roethlisberger and Lawler. Two theories, namely those of Schein and Skinner were used with no success in respect of one personnel group only. The theories of Mayo and McClelland were both used without success in respect of two personnel groups. All the others were used with no success in the case of four or more personnel groups. The theory of McCregor, although being the third most popular one, was used without success in respect of no less than 8 of the 11 personnel groups.
In most cases the percentage of users experiencing no success at all is below $10 \%$, but in a few cases it varied be tween $10 \%$ and $22,3 \%$. In one instance no less than $50 \%$ of the users achieved no success (McClelland's theory in respect of Black blue collar workers) and in one case $100 \%$ of the users obtained no success at all, namely Schein's theory in the case of Asian white collar workers.

On average the theory of Schein showed the highest percentage of no success, namely $9,1 \%$, followed by Blake and Mouton $(7,8 \%)$, Likert $(6,4 \%)$, Vroom $(5,8 \%)$ and McClelland $(5,2 \%)$. In total an average of $2,9 \%$ of the users had no success at all, the lowest being $1,1 \%$ in respect of lower management and the highest 9,0\% in the case of Black blue collar workers. 
Table 6 The most successful motivation theories for the various groups of personnel (excluding those mentioned under 'Others')

\begin{tabular}{|c|c|c|c|c|c|c|}
\hline Personnel group & $\begin{array}{c}\text { No. } 1 \\
\text { performer }\end{array}$ & $\%$ & $\begin{array}{l}\text { No. } 2 \\
\text { performer }\end{array}$ & $\%$ & $\begin{array}{l}\text { No. } 3 \\
\text { performer }\end{array}$ & $\sigma_{0}$ \\
\hline Top management & McClelland & 59,1 & McGregor & 52,4 & Maslow & 47,0 \\
\hline Middle management & Mcclelland & 50,0 & Maslow & 45,8 & Mayo & 42,9 \\
\hline Lower management & Skinner & 54,6 & Maslow & 47,0 & Mayo & 46,7 \\
\hline $\begin{array}{l}\text { White white } \\
\text { collar workers }\end{array}$ & Schein & 80,0 & Mayo & 54,5 & Herzberg & 39,5 \\
\hline $\begin{array}{l}\text { White blue } \\
\text { collar workers }\end{array}$ & Schein & 75,0 & Mayo & 44,4 & McGregor & 42,8 \\
\hline $\begin{array}{l}\text { Coloured white } \\
\text { collar workers }\end{array}$ & Mayo & 62,5 & $\begin{array}{l}\text { Lawler } \\
\text { Schein } \\
\text { Skinner }\end{array}$ & $\begin{array}{l}50,0 \\
50,0 \\
50,0\end{array}$ & - & - \\
\hline $\begin{array}{l}\text { Coloured blue } \\
\text { collar workers }\end{array}$ & Schein & 100,0 & Mayo & 57,1 & Roethlisberger & 50,0 \\
\hline $\begin{array}{l}\text { Asian white } \\
\text { collar workers }\end{array}$ & McClelland & 58,3 & Mayo & 42,9 & Gellerman & 42,8 \\
\hline $\begin{array}{l}\text { Asian blue } \\
\text { collar workers }\end{array}$ & Schein & 100,0 & Skinner & 55,6 & Mayo & 42,9 \\
\hline $\begin{array}{l}\text { Black white } \\
\text { collar workers }\end{array}$ & Gellerman & 42,8 & Skinner & 40,0 & Maslow & 37,3 \\
\hline $\begin{array}{l}\text { Black blue } \\
\text { collar workers }\end{array}$ & $\begin{array}{l}\text { Mayo } \\
\text { Vroom } \\
\text { Skinner }\end{array}$ & $\begin{array}{l}50,0 \\
50,0 \\
50,0\end{array}$ & - & - & - & - \\
\hline
\end{tabular}

Table 4 gives details regarding the percentage of users experiencing a success rate of $1 \%$ to $49 \%$. It is clear that a success rate of $1 \%$ to $49 \%$, which must be regarded as very disappointing, was reached in respect of all personnel groups by a large percentage of users. In the case of Roethlisberger, for example, this rate was attained by $100 \%$ of the users in respect of no less than 6 of the 11 personnel groups. In quite a number of cases $70 \%$ and more of the users experienced such a low success rate. In total a success rate of $1 \%$ to $49 \%$ was experienced by more than $50 \%$ of the users in respect of all personnel groups - the lowest being $54,9 \%$ in the case of top management, the highest $71,1 \%$ in respect of Coloured blue collar workers and the average $62,0 \%$. On average the theory of Roethlisberger showed such a low success rate in no less than $84,7 \%$ of the users, followed by Vroom $(77,2 \%)$, Likert $(76,5 \%)$ and no less than six others with such a rate in more than $60 \%$ of the users.

Table 5 provides information on the percentage of users experiencing a success rate of $50 \%$ and more.

This table reveals that except in the case of the theories mentioned under 'others', a success rate of $50 \%$ and more was experienced by a disappointingly low percentage of the users of those theories. Only in a limited number of cases this success rate was obtained by more than $50 \%$ of the users, e.g. Schein's theory in respect of four personnel groups, Skinner's theory in the case of two groups, Mayo's theory in respect of three groups, and McClelland's theory in the case of two groups. The three most popular theories (those of Maslow, Herzberg and McGregor) obtained such success in less than $50 \%$ of the users in respect of all personnel groups, except the theory of McGregor in the case of top management $(52,4 \%)$.

In total a success rate of $50 \%$ and more was experienced by less than $50 \%$ of the users in respect of all personnel groups - the lowest being $27,7 \%$ in the case of Coloured blue collar workers, the highest $43,2 \%$ in respect of top management, and the average only $35,1 \%$. On average the theories mentioned under 'others' obtained the best results, namely a success rate of $50 \%$ and more in $79,6 \%$ of the users, followed by the theories of Mayo $(46,7 \%)$ and Schein $(45,1 \%)$. All the others achieved an average of less than $40 \%$ in respect of the eleven personnel groups at this level.

\section{The most successful motivation theories/ideas}

Table 6 gives information on the three most successful motivation theories/ideas in respect of each of the eleven personnel groups, taking a success rate of $50 \%$ and more as criterion, disregarding the number of cases in which each person's theory/ideas were used and excluding those theories mentioned under 'others'.

From this information it is clear that there is no correlation between the popularity of a motivation theory and its successful application. It has been shown previously that the most popular theories were those of Maslow, Herzberg, McGregor and to a lesser extent that of Blake and Mouton. However, none of these obtained a position of best performer in respect of any of the 11 personnel groups. McGregor's theory came second in the case of top management and third in the case of White blue collar workers. Maslow's theory obtained second place in the case of middle and lower management and third place in the case of top management and Black white collar workers. Herzberg's theory obtained its best performance in the case of White white collar workers where it reached a third place. The theory of Blake and Mouton never reached the three best performers.

\section{Conclusion}

In so far as this survey can be regarded as fairly representative of the South African scene, the following conclusion can be drawn

(a) The survey has revealed that South African companies are not using motivation theories/ideas very extensively 
- the highest application rate of any theory being $44,5 \%$ only.

(b) Motivation theories/ideas are used more often in respect of management personnel and White white collar workers than in the case of the other worker groups - the highest application rate being $33,6 \%$ only in respect of the latter.

(c) The most popular motivation theories/ideas are those of Maslow, Herzberg and McGregor, whilst the theories of Roethlisberger, Schein, Vroom and Lawler are used least.

(d) As far as the successfulness of the various persons' motivation theories/ideas is concerned, the results of the survey are also disappointing. It shows that almost all the theories have been used without success in respect of one or more personnel groups. It also reveals that most of the companies using them have experienced a success rate of less than $50 \%$. Only in a few cases a success rate of $75 \%$ and more has been obtained.

(e) The most successful motivation theories/ideas in respect of each personnel group has been determined, but it is clear that there is very little correlation if any, between the popularity of a motivation theory and the success attained by using it. 